\title{
FAKTOR PENYEBAB PENYAKIT AKIBAT KERJA PADA PEKERJA LAS
}

\section{Factor Related with Occupational Disease on Welders}

\author{
Husaini, Ratna Setyaningrum, Maman Saputra \\ Program Studi Kesehatan Masyarakat, Fakultas Kedokteran, Universitas Lambung \\ Mangkurat, Provinsi Kalimantan Selatan, Indonesia \\ (husainifawaz@yahoo.com)
}

\begin{abstract}
ABSTRAK
Pengelasan merupakan tempat kerja yang berisiko tinggi menimbulkan gangguan kesehatan. Penelitian ini bertujuan mengidentifikasi dan menganalisis faktor yang berhubungan dengan Penyakit Akibat Kerja (PAK) pada pekerja las di Jalan A.Yani, Kota Banjarbaru. Desain penelitian adalah observasional analitik menggunakan metode cross sectional. Jumlah sampel berdasarkan quota sampling sebanyak 30 orang. Hasil menunjukkan tidak ada hubungan antara usia $(p=0,513)$, masa kerja $(p=0,729)$, lama kerja $(p=0,337)$ terhadap PAK. Namun, ada hubungan pengetahuan $(\mathrm{p}=0,046)$ dan penggunaan APD $(\mathrm{p}=0,000)$ terhadap PAK. Secara simultan usia, masa kerja, lama kerja, tingkat pengetahuan, dan penggunaan APD tidak berhubungan dengan kejadian PAK pada pekerja las. Secara parsial tingkat pengetahuan dan penggunaan APD hubungan parsial yang signifikan terhadap penyakit akibat kerja pada pekerja las. Tukang las yang memiliki tingkat pengetahuan yang kurang berisiko 5,442 kali lebih besar dibanding yang memiliki tingkat pengetahuan baik. Tukang las yang tidak menggunakan minimal empat APD utama berisiko 1,000 kali lebih besar dibanding yang menggunakan minimal empat APD utama. Tidak ada hubungan yang signifikan antara usia, masa kerja, dan lama kerja dengan penyakit akibat kerja. Ada hubungan antara tingkat pengetahuan dan penggunaan APD terhadap penyakit akibat kerja.
\end{abstract}

Kata kunci: Penyakit akibat kerja, pekerja las

\section{ABSTRACT}

Welders a workplace with high-risk activity that can cause health problems. This study aims to identify and analyze the factors related with occupational diseases on welders in A. Yani Street, Banjarbaru.The study design was observational analytic using cross sectional method. Sample base on quota sampling of 30 respondent. The results showed no relationship between age $(p=0,513)$, tenure $(p=0,729)$, length of work $(p=0,337)$ with occupational disease. But, there was a relationship between knowledge $(p=0,046)$ and use of PPE $(p=0,000)$ with occupational disease. Simultaneously age, tenure, length of work, the level of knowledge and use of PPE is not related with the incidence of occupational disease on welders. Partially level of knowledge and use of PPE partial relationship significant to occupational diseases on welders. Welders who have less knowledge that is 5.442 greater risk than those with a good level of knowledge. Welder who have not use at least 4 major of PPE 1,000 greater risk than those who use at least four major of PPE. There is no significant relationship between age, tenure, and length of work with occupational disease. There is a relationship between the level of knowledge and use of PPE with occupational diseases.

Keywords: Occupational diseases, welders 


\section{PENDAHULUAN}

Masalah Keselamatan dan Kesehatan Kerja (K3) secara umum di Indonesia masih sering terabaikan. Hal ini ditunjukkan dengan masih tingginya angka kecelakaan kerja. Pada tahun 2014, terdapat 40.694 kasus Penyakit Akibat Kerja (PAK) di Indonesia. Sebanyak 418 kasus terjadi di Kalimantan Selatan. ${ }^{1}$

Penyakit Akibat Kerja (PAK) dan Kecelakaan Kerja (KK) di kalangan masyarakat di Indonesia belum tercatat dengan baik. Jika dilihat angka kecelakaan dan penyakit akibat kerja di beberapa negara maju (dari beberapa pengamatan) menunjukkan kecenderungan peningkatan prevalensi. Sebagai faktor penyebab, sering terjadi karena kurangnya kesadaran pekerja dan kualitas serta keterampilan pekerja yang kurang memadai. Banyak pekerja yang meremehkan risiko kerja, sehingga tidak menggunakan alat-alat pengaman walaupun sudah tersedia. Penjelasan Undang-Undang Nomor 23 Tahun 1992 tentang Kesehatan telah mengamanatkan antara lain, setiap tempat kerja harus melaksanakan upaya kesehatan kerja, agar tidak terjadi gangguan kesehatan pada pekerja, keluarga, masyarakat dan lingkungan disekitarnya. ${ }^{2}$ Penyakit akibat kerja disebabkan oleh dua faktor, yaitu lingkungan kerja dan hubungan kerja. Penyakit akibat kerja atau berhubungan dengan pekerjaan dapat disebabkan oleh pemajanan di lingkungan kerja. ${ }^{3}$

Industri pengelasan merupakan tempat kerja dengan aktivitas yang berisiko tinggi yang dapat menimbulkan gangguan kesehatan dan kelelahan kerja yang berdampak pada kecelakaan kerja. Di Indonesia, bengkel las mudah dijumpai di pinggir jalan. ${ }^{4}$ Beberapa bengkel las berada pada jalan raya yang ramai dilewati oleh masyarakat umum seperti yang terdapat di sepanjang jalan A. Yani Kota Banjarbaru yang merupakan jalur utama antar provinsi di Kalimantan Selatan. Aktivitas jalan raya dapat menimbulkan kebisingan lalu lintas di jalan raya yang tinggi yang dapat menimbulkan ketidaknyamanan yang mengganggu konsentrasi kerja sehingga pekerja dapat mengalami kelelahan dan menyebabkan penyakit akibat kerja.

Hasil penelitian Zulfina menyebutkan bahwa sebanyak $63 \%$ pekerja las mengalami kelelahan kerja berat sehingga dapat berakibat pada kejadian kecelakaan kerja dan penyakit akibat kerja. ${ }^{5}$ Penelitian ini bertujuan mengetahui faktor penyebab penyakit akibat kerja pada pekerja las di sepanjang jalan A. Yani Kota Banjarbaru. Pentingnya penggunaan APD dalam bekerja di bagian las diperlukan oleh pekerja dan bagi pemilik industri yang merupakan kewajiban yang tidak terpisahkan. Begitu juga dengan faktor usia, masa kerja, lama kerja, peningkatan pengetahuan juga merupakan bagian penting untuk mencegah terjadinya penyakit akibat kerja.

\section{BAHAN DAN METODE}

Metode penelitian yang digunakan adalah cross sectional. Sampel yang digunakan adalah quota sampling sebanyak 30 responden. Instrumen yang digunakan dalam penelitian adalah kuesioner. Kuesioner digunakan untuk mengetahui kecelakaan kerja, usia kerja, masa kerja, lama kerja, tingkat pengetahuan dan penggunaan Alat Pelindung Diri (APD). Variabel bebas pada penelitian adalah usia kerja, masa kerja, lama kerja, tingkat pengetahuan, sedangkan variabel terikat dalam penelitian ini adalah penyakit akibat kerja. Analisis data dilakukan secara univariat, bivariat dan multivariat. Analisis univariat untuk mengetahui distribusi frekuensi dari variabel yang diteliti. Analisis bivariat untuk mengetahui hubungan antara masing-masing variabel bebas dengan variabel terikat, sedangkan analisis multivariat untuk mengetahui hubungan secara simultan dan parsial dari setiap variabel bebas terhadap variabel terikat dan mengetahui nilai ekspektasi atau Odds Ratio (OR). Bahan yang digunakan dalam penelitian ini, yaitu panduan dengan kuesioner, semua data dianalisa menggunakan uji statistik analisis univariat dan analisis bivariat (chi square) serta analisis multivariat (uji regresi).

\section{HASIL}

Penyakit akibat kerja yang dapat diderita oleh pekerja las diantaranya adalah sakit di tengkuk, bahu, dada, pinggang, perut, punggung, paha, pergelangan tangan, lutut, betis, atau pergelangan kaki. Selain itu, bisa juga terkena penyakit seperti batuk, gatal pada kulit dan mata, mata perih dan demam. Berikut distribusi frekuensi kondisi pekerja las di Jalan A. Yani Kota Banjarbaru.

Sebanyak 5 orang $(16,67 \%)$ pekerja mengalami gejala PAK, baik saat, sebelum, atau se- 
Tabel 1. Faktor Penyakit Akibat Kerja pada Pekerja Las

\begin{tabular}{|c|c|c|c|c|c|c|c|c|}
\hline \multirow{3}{*}{ Variabel } & \multicolumn{4}{|c|}{ Menderita Penyakit Akibat Kerja } & \multirow{2}{*}{\multicolumn{2}{|c|}{ Total }} & \multirow{2}{*}{\multicolumn{2}{|c|}{ Hasil Statistik }} \\
\hline & \multicolumn{2}{|c|}{ Ya } & \multicolumn{2}{|c|}{ Tidak } & & & & \\
\hline & $\mathbf{n}$ & $\%$ & $\mathbf{n}$ & $\%$ & $\mathbf{n}$ & $\%$ & $\mathbf{p}$ & OR \\
\hline \multicolumn{9}{|l|}{ Usia } \\
\hline Usia muda ( $<40$ tahun) & 5 & 17,86 & 23 & 82,14 & 28 & 100 & 0,513 & \\
\hline Usia tua ( $>40$ tahun) & 0 & 0,00 & 2 & 100 & 2 & 100 & & \\
\hline \multicolumn{9}{|l|}{ Masa kerja } \\
\hline Masa kerja $<5$ tahun & 3 & 15,00 & 17 & 85,00 & 20 & 100 & 0,729 & \\
\hline Masa kerja $\geq 5$ tahun & 2 & 20,00 & 8 & 80,00 & 10 & 100 & & \\
\hline \multicolumn{9}{|l|}{ Lama kerja } \\
\hline Lama kerja 6-8 jam & 0 & 0,00 & 4 & 100 & 4 & 100 & 0,337 & \\
\hline Lama kerja 8-10 jam & 5 & 19,23 & 21 & 80,77 & 26 & 100 & & \\
\hline Lama kerja 10 jam per hari & 0 & 0,00 & 0 & 0,00 & 0 & 100 & & \\
\hline \multicolumn{9}{|l|}{ Tingkat Pengetahuan } \\
\hline Pengetahuan Baik & 5 & 29,41 & 12 & 70,59 & 17 & 100 & 0,046 & 5,442 \\
\hline Pengetahuan Kurang & 0 & 0,00 & 13 & 100 & 13 & 100 & & \\
\hline \multicolumn{9}{|l|}{ Penggunaan APD } \\
\hline Menggunakan minimal 4 APD utama & 0 & 0,00 & 0 & 0,00 & 0 & 100 & 0,000 & 1,500 \\
\hline Tidak menggunakan 4 APD utama & 5 & 16,67 & 25 & 83,33 & 30 & 100 & & \\
\hline
\end{tabular}

sudah bekerja, sedangkan sebanyak 25 orang $(83,33 \%)$ tidak mengalami gejala PAK. Sebagian besar usia pekerja kategori usia muda ( $<40$ tahun) sebanyak 28 orang $(93,33 \%)$, sedangkan pekerja kategori usia tua ( $>40$ tahun) sebanyak 2 orang $(6,67 \%)$. Sebanyak 20 orang $(66,67 \%)$ memiliki masa kerja kurang dari 5 tahun, sedangkan masa kerja yang lebih dari 5 tahun sebanyak 10 orang $(33,33 \%)$. Berdasarkan lama kerja, sebagian besar antara 8-10 jam per hari sebanyak 26 orang $(86,67 \%)$, sedangkan lama kerja 6-8 jam per hari sebanyak 4 orang $(13,33 \%)$ dan tidak ada $(0,00 \%)$ yang bekerja selama 10 jam per hari. Pekerja yang memiliki tingkat pengetahuan baik sebanyak 17 orang $(56,67 \%)$ dan yang memiliki tingkat pengetahuan kurang baik sebanyak 13 orang $(43,33 \%)$. Tidak ada pekerja yang menggunakan APD minimal empat APD utama. Hal ini berarti sebanyak 30 orang $(100 \%)$ tidak menggunakan empat APD utama (Tabel 1).

APD yang digunakan sebagian besar hanya kacamata las dan sarung tangan (76,67\%). Sebanyak 23 orang $(76,67 \%)$ pekerja las yang menggunakan APD jenis sarung tangan. Sebanyak 8 orang $(26,67 \%)$ pekerja las yang menggunakan APD jenis masker/penutup hidung dan muka. Sebanyak 14 orang $(46,67 \%)$ pekerja las yang menggunakan APD jenis sepatu kulit. Sebanyak 23 orang (76,67\%) pekerja las yang menggunakan APD jenis kaca mata hitam/anti cahaya api. Sebanyak
6 orang $(20,00 \%)$ pekerja las yang menggunakan APD jenis topi, sedangkan sebanyak 2 orang $(26,67 \%)$ pekerja las yang menggunakan APD jenis baju kerja (Tabel 2).

Hasil penelitian yang diperoleh menunjukkan bahwa responden yang berusia muda ( $<40$ tahun) maupun yang berusia tua ( $>40$ tahun), memiliki risiko dan peluang yang sama untuk menderita PAK. Hasil uji statistik diperoleh nilai $\mathrm{p}=0,513$. Hal ini berarti tidak ada hubungan antara usia kerja dengan kejadian PAK. Hasil penelitian yang diperoleh menunjukkan bahwa responden yang memiliki masa kerja $<5$ tahun maupun yang memiliki masa kerja $\geq 5$ tahun, memiliki risiko dan peluang yang sama untuk menderita PAK. Hasil uji statistik diperoleh nilai $p=0,729$. Hal ini berarti tidak ada hubungan antara masa kerja dengan kejadian PAK. Hasil penelitian yang diperoleh menunjukkan bahwa responden yang bekerja selama 6-8 jam per hari maupun 8-10 jam per hari, memiliki risiko dan peluang yang sama untuk menderita PAK. Hasil uji statistik diperoleh nilai $p=0,337$, hal ini berarti tidak ada hubungan antara lama kerja dengan kejadian PAK (Tabel 1).

Hasil penelitian yang diperoleh menunjukkan bahwa responden yang memiliki tingkat pengetahuan kurang baik berisiko dan berpeluang 5,442 kali lebih besar untuk menderita PAK. Hasil uji statistik diperoleh nilai $\mathrm{p}=0,046$, hal ini berarti ada hubungan antara tingkat pengetahuan dengan 
Tabel 2. Jenis APD pada Pekerja Las

\begin{tabular}{lcc}
\hline \multicolumn{1}{c}{ Jenis APD } & n & \% \\
\hline Sarung tangan & 23 & 76,67 \\
Masker/penutup hidung dan muka & 8 & 26,67 \\
Sepatu kulit & 14 & 46,67 \\
Kaca mata hitam/anti cahaya api & 23 & 76,67 \\
Topi & 6 & 20,00 \\
Baju kerja & 2 & 6,67 \\
\hline
\end{tabular}

kejadian PAK. Hasil penelitian yang diperoleh menunjukkan bahwa responden yang tidak menggunakan minimal empat APD utama selama bekerja berisiko dan berpeluang 1,500 kali lebih besar untuk menderita PAK. Hasil uji statistik diperoleh nilai $\mathrm{p}=0,000$, hal ini berarti ada hubungan antara penggunaan APD dengan kejadian PAK (Tabel 1).

Secara simultan variabel independen tidak berhubungan dengan kejadian PAK pada pekerja las. Untuk melihat kemampuan variabel independen dalam menjelaskan variabel dependen digunakan uji regresi dengan nilai $R$ Square yang didapatkan sebesar 0,342 yang menunjukkan bahwa kemampuan variabel independen dalam menjelaskan variabel dependen sebesar 0,342 atau sebesar $34,2 \%$ dan terdapat $100 \%-34,2 \%=65,8 \%$ di luar model yang menjelaskan variabel dependen (Tabel 1).

\section{PEMBAHASAN}

Hasil penelitian menunjukkan bahwa tidak ada hubungan antara usia dengan PAK. Usia memang memiliki pengaruh terhadap PAK. ${ }^{7}$ Golongan usia tua mempunyai kecenderungan yang lebih tinggi untuk mengalami kecelakaan akibat kerja dibandingkan dengan golongan usia muda karena usia muda mempunyai reaksi dan kegesitan yang lebih tinggi. ${ }^{8}$ Dalam beberapa kasus, tenaga kerja berusia tua cenderung mengalami penyakit akibat dari penurunan kualitas fisik. ${ }^{9}$ Namun, usia muda juga sering pula mengalami penyakit akibat kerja, hal ini mungkin karena kecerobohan dan sikap suka tergea-gesa. Dari hasil penelitian di Amerika Serikat diungkapkan bahwa pekerja usia muda lebih banyak mengalami penyakit akibat kerja dibandingkan dengan pekerja yang lebih tua. Pekerja usia muda biasanya kurang berpengalaman dalam pekerjaanya. ${ }^{10}$

Banyak alasan tenaga kerja golongan umur muda mempunyai kecenderungan untuk menderita penyakit akibat kerja lebih tinggi dibandingkan dengan golongan umur yang lebih tua. Beberapa faktor yang memengaruhi tingginya kejadian penyakit akibat kerja pada golongan umur muda antara lain karena kurang perhatian, kurang disiplin, cenderung menuruti kata hati, ceroboh dan tergesa-gesa. ${ }^{11}$

Hasil penelitian menunjukkan bahwa tidak ada hubungan antara masa kerja dengan penyakit akibat kerja. Masa kerja berhubungan langsung dengan pengalaman kerja, semakin lama masa kerja seseorang maka semakin tinggi pengalaman dan jam terbang pekerja tersebut, sehingga pekerja akan mampu lebih memahami tentang cara bekerja dengan aman untuk menghindarkan diri mereka dari penyakit akibat kerja. Tenaga kerja yang baru umumnya belum mengetahui secara mendalam seluk beluk pekerjaan. Sebaliknya dengan bertambahnya masa kerja seseorang tenaga kerja maka bertambah pula pengetahuan dan keterampilan yang dimiliki pekerja dan aspek keselamatan dari pekerjaan yang dilakukan. ${ }^{12}$

Hasil penelitian ini sejalan dengan penelitian Hernawati dan Hikmawan, Moradinazar et al., yang menunjukkan bahwa tidak ada hubungan masa kerja dengan penyakit akibat kerja. Masa kerja yang tinggi tidak menjamin seseorang aman dari penyakit, hal-hal seperti mengabaikan kondisi tidak aman dan tindakan tidak aman serta paparan bahan toksik yang berlangsung lama dapat berakibat fatal bagi pekerja itu sendiri. ${ }^{13,14}$

Hasil penelitian menunjukkan bahwa tidak ada hubungan antara lama kerja dengan penyakit akibat kerja. Seseorang dapat bekerja dengan baik dalam sehari selama 8 jam atau 40 jam dalam seminggu. Waktu sisa dalam satu hari (16 jam) dipergunakan untuk kehidupan dalam keluarga dan masyarakat, istirahat dan lain-lain. ${ }^{13}$ Jam kerja dapat memengaruhi penyakit akibat kerja, karena jam kerja yang lama dapat menyebabkan kelelahan dan memperbesar risiko penyakit akibat kerja. ${ }^{14,15}$ Namun, pada penelitian ini, lama kerja tidak berhubungan dengan penyakit akibat kerja karena hanya merupakan salah satu faktor yang mungkin memengaruhi terjadinya penyakit akibat kerja.

Hasil penelitian menunjukkan bahwa ada hubungan antara tingkat pengetahuan dengan penyakit akibat kerja. Pekerja yang memiliki penge- 
tahuan yang kurang tentang cara bekerja dan keselamatan kerja dapat menimbulkan penyakit akibat kerja. ${ }^{16}$ Selain itu, perilaku seseorang seringkali dipengaruhi oleh tingkat pengetahuannya. ${ }^{17}$ Pengetahuan seseorang tentang faktor bahaya, sumber bahaya dan jenis bahaya di tempat kerja yang kurang akan berdampak pada kesadaran untuk melindungi diri dari berbagai macam potensi bahaya kerja. ${ }^{18}$

Hasil penelitian menunjukkan bahwa responden yang memiliki pengetahuan yang kurang berisiko 5,442 kali lebih besar terkena penyakit akibat kerja dibandingkan dengan responden yang memiliki pengetahuan yang baik. Tingkat pengetahuan dapat memengaruhi kepatuhan sese-orang dalam penggunaan APD. Hasil penelitian yang dilakukan oleh Noviandry, pada 46 pekerja pengelasan dari 12 bengkel yang ada di Kelurahan Gondrong, Kecamatan Cipondoh, Kota Tangerang yaitu menyatakan terdapat hubungan antara pengetahuan dengan penggunaan APD pada industri pengelasan informal. ${ }^{19}$ Peningkatan pengetahuan merupakan salah satu pencegahan penyakit akibat kerja dan manajemen risiko kesehatan kerja. ${ }^{20}$

Hasil penelitian menunjukkan bahwa ada hubungan antara penggunaan APD dengan kecelakaan kerja. Responden yang tidak menggunakan APD berisiko 1,500 lebih besar terhadap PAK dibandingkan dengan responden yang menggunakan APD. APD adalah salah satu pengendalian risiko pengendalian kecelakaan kerja. Penggunaan APD dapat mengurangi risiko terjadinya kecelakaan kerja dan penyakit akibat kerja. APD utama dalam pengelasan ada enam, yaitu helm atau topi penutup kepala (safety helm), kacamata las (googles), penutup muka (face shield), pakaian $\mathrm{kerja} / \mathrm{pelindung}$ dada (apron), sarung tangan (safety glove), dan sepatu kerja (safety shoes). Sarung tangan (safety glove) digunakan untuk melindungi jari-jari tangan dan kulit dari benda panas dan sengatan listrik dingin, radiasi elektromagnetik, dan radiasi mengion, bahan kimia, benturan dan pukulan, luka, lecet dan infeksi, maka tukang las harus memakai sarung tangan yang tahan panas dan bersifat isolasi terhadap listrik. Pelindung muka digunakan untuk melindungi seluruh muka terhadap kebakaran kulit sebagai akibat dari cahaya busur, percikan dan lainnya, yang tidak dapat dilindungi hanya dengan pelindung mata saja. Sepatu kerja digunakan untuk melindungi kaki dan kulit dari benda-benda tajam, kejatuhan benda-benda tajam dan percikan cairan logam serta goresan-goresan benda-benda tajam. Kaca mata las (googles) digunakan untuk menghindari pengaruh radiasi energi seperti sinar ultra violet, sinar infra merah dan lain-lain yang dapat merusak mata. Para pekerja yang kemungkinan dapat terkena bahaya dari sinar yang menyilaukan, seperti sinar las potong dengan menggunakan gas dan percikan dari sinar las yang memijar harus menggunakan pelindung mata khusus. Pekerjaan pengelasan juga menghasilkan radiasi sinar tergantung pada pada temperatur tertentu. Pakaian kerja yang digunakan waktu pengelasan berfungsi untuk melindungi anggota badan dari bahaya-bahaya waktu pengelasan. Sedangkan bagian dada merupakan bagian yang sangat peka terhadap pengaruh panas dan sinar yang tajam. Sinar dari las listrik termasuk sinar yang sangat tajam. Pelindung dada dipakai setelah baju las. ${ }^{6}$

Sebagian besar pekerja tidak patuh dalam menggunakan APD pada saat bekerja dikarenakan berbagai macam alasan, antara lain ketidaknyamanan dalam penggunaan APD selama bekerja. Ketidaknyamanan disini diantaranya adalah panas, berat, berkeringat atau lembab, sakit, pu-sing, sesak dan sebagainya. Alasan lainnya, yaitu merasa bahwa pekerja tersebut tidak berbahaya atau berdampak pada keselamatan dan kesehatannya. Terutama bagi para pekerja yang sudah bertahun-tahun melakukan pekerjaan tersebut. Kesalahpahaman terhadap fungsi APD akibat kurangnya pengetahuan akan fungsi dan kegunaan APD, APD mengganggu kelancaran dan kecepatan pekerjaan adalah alasan lain pekerja tidak patuh dalam menggunakan APD di tempat kerja.

Proses pengelasan memiliki bahaya dan risiko terjadinya penyakit akibat kerja. Beberapa bahaya yang berpotensi terjadi pada proses pengelasan adalah bahaya radiasi (cahaya), bahaya asap dan gas, bahaya percikan api, bahaya kebakaran, bahaya jatuh, dan bahaya listrik. ${ }^{21}$ Ketidaktahuan pekerja terhadap pentingnya penggunaan APD atau pekerja yang terbiasa tidak menggunakan APD, memperlambat gerakan dalam bekerja, susah bernapas bila memakai masker atau penutup muka, terasa dan menambah panas sewaktu bekerja bila menggunakan baju lengan panjang, sarung tangan, penutup kepala dan sepatu kulit menye- 
babkan risiko tinggi terhadap keselamatan dan kesehatan kerja. Keterkaitan pentingnya seorang pekerja untuk melindungi dirinya dari berbagai potensi dan risiko bahaya kerja terutama penggunaan APD mutlak diperlukan sebagai suatu kebutuhan. Sikap pekerja yang tidak mendukung berpengaruh dalam penggunaan APD. ${ }^{22}$

Secara simultan variabel independen tidak berhubungan dengan kejadian PAK pada pekerja las. Faktor usia, masa kerja, lama kerja, pengetahuan dan penggunaan APD secara simultan mungkin saja tidak berpengaruh terhadap penyakit akibat kerja, karena ada faktor-faktor lain lagi yang dapat memengaruhinya seperti tingkat kepatuhan, gizi kerja, stres kerja, kebiasaan merokok dan posisi atau sikap bekerja.

\section{KESIMPULAN DAN SARAN}

Hasil menunjukkan tidak ada hubungan antara usia $(p=0,513)$, masa kerja $(p=0,729)$, lama kerja $(p=0,337)$ terhadap PAK. Namun, ada hubungan pengetahuan $(\mathrm{p}=0,046)$ dan penggunaan APD $(\mathrm{p}=0,000)$ terhadap PAK. Secara simultan usia, masa kerja, lama kerja, tingkat pengetahuan, dan penggunaan APD tidak berhubungan dengan kejadian PAK pada pekerja las. Secara parsial tingkat pengetahuan dan penggunaan APD hubungan parsial yang signifikan terhadap penyakit akibat kerja pada pekerja las. Selain itu, secara simultan usia, masa kerja, lama kerja, tingkat pengetahuan, dan penggunaan APD tidak berhubungan dengan kejadian penyakit akibat kerja pada pekerja las. Secara parsial tingkat pengetahuan dan penggunaan APD hubungan parsial yang signifikan terhadap penyakit akibat kerja pada pekerja las. Saran kepada Pemerintah Kota Banjarbaru dan instansi di bawahnya, agar turun ke lapangan untuk pembinaan agar pekerja sektor informal seperti tukang las dalam penelitian ini dapat selalu dibina sehingga kesehatan mereka dan produktivitas tetap terjaga dengan baik.

\section{UCAPAN TERIMA KASIH}

Terima kasih kami sampaikan kepada Rektor dan Dekan Fakultas Kedokteran Universitas Lambung Mangkurat serta Ketua Prodi dan seluruh staf Program Studi S1 dan S2 Kesehatan Masyarakat Fakultas Kedokteran Universitas Lambung Mangkurat atas kerjasama dan dukung- annya. Kami ucapkan terima kasih juga kepada Pemerintah Kota Banjarbaru dan seluruh tempat pengelasan yang menjadi responden dalam penelitian ini.

\section{DAFTAR PUSTAKA}

1. Departemen Kesehatan Republik Indonesia. Pusat Data dan Informasi Kesehatan Kerja. 2011-2014. Jakarta: Depertemen Kesehatan RI. 2015.

2. Riyadina W, Suharyanto FX, and Tana L. Keluhan Nyeri Muskuloskeletal pada Pekerja Industri di Kawasan Industri Pulo Gadung Jakarta. Majalah Kedokteran Indonesia. 2008; 58(1).

3. Wichaksana A. Penyakit Akibat Kerja di Rumah Sakit dan Pencegahannya. Cermin Dunia Kedokteran. 2012; 134.

4. Azir A. Pengaruh Pemakaian Alat Pelindung Mata terhadap Ketajaman Penglihatan Pegawai Bengkel Las di Wilayah Terminal Bus Wisata Ngabean Kota Yogyakarta. Jurnal Respati. 2014; 9(3): 222-233.

5. Zulfina M. Hubungan Kelelahan Kerja dengan Kejadian Kecelakaan Kerja pada Pekerja Las di Sepanjang Jalan A. Yani Kota Banjarbaru. Jurnal Penelitian Kesehatan Masyarakat Indonesia. 2015; 3(1): 56-64.

6. Bhumika TV, Thakur M, Jaswal R, Pundird P, Rajware E. Occupational Injuries and Personal Protective Equpiments Adopted by Welding Workers: A Cross Sectional Study in South India. Journal of GJMEDPH. 2014; 3(5).

7. Reddy R, et al. Workplace Injuries in Fiji: a Population-Based Study (TRIP 7). Jurnal of Occup Med. 2013; 63: 284-286.

8. International Labour Office. Buku Pedoman Pencegahan Kecelakaan. Jakarta : PT. Pustaka Binaman Pressindo; 1989.

9. Umami, et al. Hubungan Antara Karakteristik Responden dan Sikap Kerja Duduk dengan Keluhan Nyeri Punggung Bawah (Low Back Pain) pada Pekerja Batik Tulis. e-Journal Pustaka Kesehatan. 2014; 2(1).

10. Suma'mur. Hygiene Perusahaan dan Kesehatan Kerja. Jakarta: PT. Sagung Seto; 2009.

11. Hutama AP. Hubungan antara Masa Kerja dan Penggunaan Alat Pelindung Diri dengan Kapasitas Vital Paru pada Pekerja Unit Spinning I 
Bagian Ring Frame PT. Pisma Putra Tekstil Pekalongan. Unnes Journal of Public Health. 2013; 2(3).

12. Moradinazar $M$, et al. Epidemiology of Work-Related Injuries Among Construction Workers of Ilam (Western Iran) During 2006-2009. Journal of Iran Red Crescent Med 2013;15: e8011.

13. Suma'mur, PK. Keselamatan dan Kesehatan Kerja. Jakarta: CV. Mas Agung; 1987.

14. Cecep D. S. Keselamatan dan Kesehatan Kerja. Yogyakarta: Gosyen Publishing; 2014.

15. Hedge A. Human Factors: Ergonomics, Anthropometrics and Biomechanics. Cornell University Ergonomics Web. 2003; 8(19).

16. Sarinah BK and Supri E. Hubungan Pengetahuan dan Sikap Kesehatan Kerja dengan Penyakit Akibat Kerja pada Pekerja Batu Bata. Jurnal Kesehatan Masyarakat. 2015;1(2).

17. Yasari. Perilaku Penggunaan Alat Pelindung Diri dan Kejadian Dermatitis Akibat Kerja pada Pekerja Pengangkut Sampah di PT. USB
Kota Jambi [Tesis]. Yogyakarta: Universitas Gadjah Mada;2008.

18. Husaini. Relationship Exposure $\mathrm{CO}, \mathrm{SO}_{2}$, $\mathrm{NO}_{2}$, Fume and Vapor With Lung Function and Immunoglobulin Serum levels of Blacksmith. Disertation of Doctoral Program-Medicine and Health Sciences Graduate Program of the Faculty of Medicine, University of Gadjah Mada. Indonesia. 2014. 54-55.

19. Daniel. Prinsip Ergonomik Kurangi Gangguan Kesehatan Kerja. Jurnal Farmacia. 2006;5(6).

20. Kurniawidjaja LM. Program Perlindungan Kesehatan Respirasi di Tempat Kerja Manajemen Risiko Penyakit Paru Akibat Kerja. Jurnal Respirasi Indonesia. 2010; 30(4).

21. Notoatmodjo S. Pendidikan dan Perilaku Kesehatan. Jakarta: Rineka Cipta;2012.

22. Ahmad R. Hubungan Pengetahuan dan Sikap Karyawan dengan Penggunaan Alat Pelindung Diri (APD) pada PT. Harta Samudra Pelabuhan Perikanan Nusantara Ambon Tahun 2012. Jurnal Pelangi Ilmu. 2012;5(2). 